$$
\text { 메니에르병의 병인론 }
$$

서울대학교 의과대학 보라매병원 이비인후과학교실

이 준 호

\title{
Pathophysiology of Meniere's Disease
}

Jun Ho Lee, MD

Department of Otorhinolaryngology-Head and Neck Surgery, Seoul National University College of Medicine, Boramae Hospital, Seoul, Korea

\section{서 론}

2005년 4월 2일부터 5일까지 L.A에서 개최되었던 5th Meniere's Disease \& Inner Ear Homeostasis Disorders Symposium에서 University of Washington 의 George A. Gates는 메니에르병에 대하여 다음과 같 은 근본적인 질문들이 있지만 해답은 아직 없다 하였다. 1) 메니에르병의 원인, 기전, 자연적 경과가 무엇인가, 2) 메니에르병이 하나 이상의 질환 군인가, 3) 확진이 가능한 방법은 무엇인가, 4) 내과적 치료 효과에 대한 증 거는 무엇인가, 5) pressure therapy 가 어떻게 작용하는 가, 6) 전신마취 하에 행해지는 여러 가지 수술법이 왜 비슷한 효과를 가져 오는가 등이다. 1861년 Prosper Meniere가 Medical Journal of Paris에 현재의 메니에 르병에 대해서 기존의 brain origin이라는 개념과 달리 labyrinthine origin으로 언급하는 큰 기여를 한 이래, 143년이 지난 현재에도 메니에르병을 정확히 이해하지 못하고 있는 실정이다. 저자는 그 이유로 들 수 있는 것 으로 첫째, 정상 내이 생리 과정에 대한 이해가 많이 부 족하고, 둘째, 동물에서의 실험적 내림프 수종이 인간의 메니에르병과 같을 수 없다는 점이 있으며, 셋째, 비교적

교신저자 : 이준호, 156- 707 서울 동작구 보라매길 31- 1 서울대학교 의과대학 보라매병원 이비인후과학교실 전화 : (02) 840- 2412. 전송 : (02) 831- 2826 E- mail : jlee@brm.co.kr
자세히 연구된 원인으로 여겨지는 요소들이 어떤 기전 에 의해서 내림프 수종을 만드는지에 대한 증거가 없기 때문이라고 생각된다. 임상적인 측면에서 다양하게 연구 된 병인론은 흔히 애기하는 대가들에 의해서 최근 잘 정리가 되어 있고, 관련 학회에서 다루어 온 주제이므로, 여기에서 다시 자세히 반복할 필요는 없다는 생각으로 간단히 기술하려 한다. 그러나, 내이 volume flow 조절 과 동물 모델, 항상성 조절에 대한 내용은 정리가 되어 있지도 않고, 국내에 잘 알려져 있지도 않아서, 최근 보 고를 중심으로 집중적으로 기술하려 한다. 그리고, 최근 의 심포지움에서 논의된 내용 중 일부를 발췌하려 한다 ( unpublished observation).

\section{Proposed Pathogensis of Meniere's Disease}

Minesota Ear, Head \& Neck Clinic의 Michael M. Paparella ${ }^{1)}$ 에 의하면 가장 중요한 원인의 근간이 되는 것은 multifactorial inheritance로 요약된다. Intrinsic or Genetic cause의 증거로서는 1) Hy poplasia of mastoid air cell system, 2) Hypoplasia of vestibular aqueduct and sac, 3) Reduction of Trautmann's triangle and anteromedial displacement of sigmoid sinus, 4) Hypoplasia of aditus ad antrum and facial recess in contiguity, 5) Racial genetic factors, 6) Physical anomaly that can only be explained on a genetic 
basis, 7) High incidence of bilaterality, 8) Results of chromosomal and molecular biologic studies, 9) A utoimmunity, 10) Otosclerosis 등을 들 수 있다. Extrinsic cause에 대한 증거로서는 1) T rauma(physical or acoustic), 2) Chronic otitis media and chronic mastoiditis, 3) Delayed hydrops and Meniere's disease many years after meningitis or measles in childhood, 4) Perilymphatic fistula, 5) Episode of sudden deafness, 6) Viral infection 등을 들 수 있다 하였다. 그 기전에 대해서는 Paparella는 전정수도관과 내림프낭에서의 흡수부전으로 믿고 있다. 특히 Paparella 는 수년후 재발된 환자의 재수술의 경우에서 내림프낭 의 fibroblastic proliferation과 혹은 granulation tissue 를 발견하였었고, 삽입한 silicone T - strut의 색깔이 내 림프낭의 생화학적 변화를 암시하는 노란색으로 변해 있 다는 점이 더욱 내림프낭의 흡수부전이 그 기전으로 믿 게 한다 ${ }^{2}$ 하였지만, 직접적인 증거가 될 수는 없다는 생 각이 든다. University of Pittsburgh의 Isamu Sando ${ }^{3)}$ 는 메니에르병 환자의 histopathology 에 중점을 두고 연 구해 왔다. 환자의 전체 측두골을 놓고 병리학적 연구를 하는 것은 메니에르병의 병인을 알 수 있는 좋은 방법이 긴 하지만, 그 자신이 지적하였듯이, 대개의 측두골들이 환자가 진단받은 이후 수년이 지난 후에 얻을 수 있었고, 또한 사후 변화가 중등도 있을 수 있으며, 환자의 병력에 대한 정보가 부재하다는 점 등이 문제가 되며, 이러한 점 들이 개선된다면 좀 더 정확한 정보를 얻을 수 있을 것 으로 기대하고 있다고 하였다.

\section{Absence of Longitudinal Enolymphatic Volume Flow in Normal State}

Washington university 의 생리학자 A lec N. Salt에 의해서" endolymphatic flow에는 longitudinal flow 가 있다" 는 전통적인 개념이 틀린 것으로 보고되고 있 다. ${ }^{4) 5)}$ 그의 최근의 website(http://oto.wustl.edu/cochlea/res1.htm)와 논문들에 근거하여 결론적으로 기 술하면, 정상상태에서는 내림프내의 $\mathrm{K}^{+}$turnover rate 를 설명할 정도의 longitudinal flow 는 존재하지 않는다 는 것이다. 여기서 언급되는 정상 상태는 보통의 주위의
소음, 정상 청력 과정 등이 포함되는 의미이다(personal communication). 따라서 정상적으로 longitudinal flow 가 존재한다는 것을 전제로 하여 어떤 원인에 의해서 내 림프낭의 흡수부전으로 메니에르병이 생길 수 있다는 기 존의 믿음들은 현재로서는 틀린 이론으로 봐야 한다. 그 러나, 내림프내 volume overload 혹은 volume deprivation이 생기면 그에 따른 flow 가 생긴다는 것이다.

\section{Endolymph electrolyte turnover rate}

기니픽의 내림프 $\mathrm{K}^{+}, \mathrm{Cl}^{-}, \mathrm{Na}^{+}$의 순환 반감기는 각각 $55,69,33$ 분인 것으로 측정된다. ${ }^{6) 7)}$ Radiotracer 연구 에서는 내림프 순환이 혈장이 아니라 외림프액과 순환 되는 것으로 알려져 있다. ${ }^{8)}$ 문제는 water transport가 같이 일어나는 volume flow 를 동반하느냐, 동반되지 않 느냐에 대한 명확한 구분없이 기존의 연구논문들이 기 술되어 왔다는 데에 있다.

\section{Longitudinal flow}

Salt는 iontopheresis를 이용하여 기니픽 내림프에 용 량에 변화를 주지 않으면서 marker를(T etramethy lammonium, T rimethy Ipheny lammonium, T etraethylammonium) 를 미세 파이펫을 이용하여 주입하여, 주입 지점을 기준으로 첨단부, 기저부 쪽으로의 같은 거리에서 marker들의 농도를 재었다 T hree electrodes method, Fig. 1). Flow rate가 각 방향으로 0.004 와 $0.007 \mathrm{~mm} /$ $\min$ 으로 측정되었는데, 이것은 O(zero) 과 다르지 않은 값이기 때문에 marker들의 움직임은 flow 에 의한 것이 기 보다는 단순 diffusion에 의한 것이라고 생각되고 있

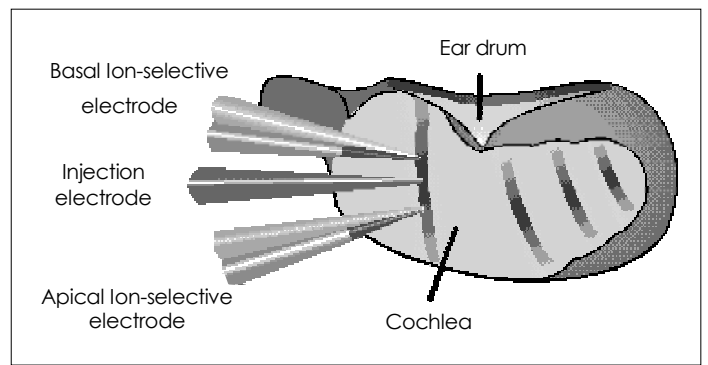

Fig. 1. Schematic drawing how three electrodes are place to measure endolymph flow in the cochlea ( adapted from Salt's webpage; http://oto.wustl.edu/cochlea/resl.htm). 
다. ${ }^{9)}{ }^{10)}$ Longitudinal flow 로써 내림프내 이온 turnover rate를 설명하기 위해서는 $0.2 \mathrm{~mm} / \mathrm{min}$ 이상 ${ }^{9}$ 이어야 하 지만, 관찰된 결과는 현저히 적은 수치이기 때문에, 이온 turnover mechanism은 주로 longitudinal flow 에 관계 없이 국소적인 기전(local mechanism)으로 이루어진다 는 것을 알 수 있다.

하지만, 이러한 고찰은 정상상태에서 longitudinal flow 가 항상성 유지에 기여하지 않는다는 것이고, 어떤 조건 에서는 flow rate가 생길 수 있다는 결과들이 있다. 내림 프에 인공 내림프를 $80 \mathrm{nl}$ 이하를 주입하였을 때는 flow 가 없었으나, 그 이상을 주입하였을 때는 $0.0067 \mathrm{~mm} / \mathrm{nl}$ 만큼 base로 향하는 flow 가 관찰된 반면, ${ }^{11)}$ 외림프액에 hy pertonic medium을 처치하여 내림프액의 volume을 줄였을 때는 apex로 향하는 flow 가 생긴다 하였다. ${ }^{10)}$ 따라서, 현재로서는, 정상적인 상태에서는 flow가 없거 나, 항상성에 기여를 못하는 아주 미약한 상태인 것으로 생각되지만, volulme disturbance가 생겼을 때는 항상 성에 영향을 줄 수 있는 flow 가 생긴다고 생각되고 있다. 이것과 연관하여 flow 의 방향이 내림프낭 쪽으로 향하 던지, 내림프낭 쪽에서 와우 방향으로 향할 때에 내림프 낭이 관여된다는 간접적인 증거가 있다. 내림프의 급성 증가는 내림프낭의 형태변화와 내림프낭에 들어있는 homogenous substance의 소실이 있었으며, ${ }^{12)}$ 내림프의 volume을 줄이는 조건에서는 homogenous substance 의 증가가 관찰되었다. ${ }^{12)}$ 따라서, 내림프낭은 내림프 volume disturbance에 매우 민감하게 반응한다고 볼 수 있다. 이러한 개념들은 다소 추론적인 면이 포함되어 있 지만, 과학적인 실험에서 얻어진 신빙성있는 데이터를 근본으로 하고 있어, 최근의 관련 논문들에서 자주 인용 되고 있으며, 최근의 메니에르 심포지움에서도 다른 발 표자들에 의해 인용되었음을 밝혀둔다.

\section{Pool concept of endolymph homeostasis}

Salt는 기존의 flow- based endolymphatic homeostasis model에 반하여," Pool concept”를 제안했다 ${ }^{13)}$ (Fig. 2). 이 가설 안에는 많은 active and passive process가 존재하며, steady state에 있거나 주기적으로 pool에 영향을 줄 수 있는 조직들이 포함되어 있다. 각 부분간의 flow는 각각의 pool의 높이에 따라서 결정된

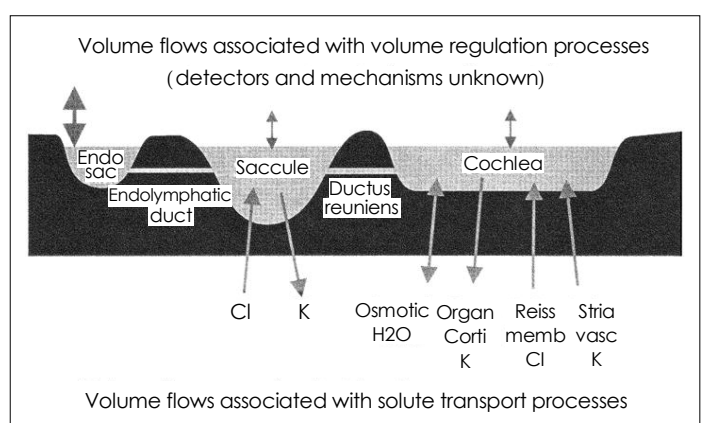

Fig. 2. "Pool" analogy for the role of endolymphatic volume flows in homeostasis. Endolymphatic compartments are represented as a number of pools connected by small ducts. Many transport processes may impact the volume status of each compartment as shown below each, but in the normal state the summed influence on volume is small. Local volume regulation processes may exist in each compartment. In the case of volulme disturbance, flow to or from the endolymphatic sac may contribute to the restoration of normal volume. Vestibular structures ( not shown) respresent additional connected pools that may also influence volume of the system (adapted from Salt, 2001).

다. 하지만, 각종의 ion transport와 연관된 내림프 volulme disturbance가 있을 수 있지만, 내이에서는 내림프 를 둘러싼 조직들의 탄력성을 감안한다면 net volume loss나 gain을 가져오는 변화만이 중요할 것이다. 실제 로, $5 \mathrm{nl} / \mathrm{min}$ 이하의 작은 volume 변화는 longitudinal flow 를 일으키지 않고 국소적으로 교정된다. ${ }^{11)}$ 국소적 기 전의 한계를 넘는 증가와 감소는 longitudinal volume flow 를 일으킨다. Saccule과 다른 평형기관에서도 가능 하지만, 아직 보고된 바는 없다. 최종적으로, 이온 항상 성에 기여를 하지는 않으면서, 용량 조절에는 역할을 할 수 있는 매우 적은 baseline longitudinal flow 가 존재할 수 있는 가능성은 남아 있다.

아무튼 이러한 개념들이 내림프낭을 파괴하여 만든 내 림프 수종 모델에서 관찰되는 적어도 수 주 동안은 내림프 이온 농도의 변화가 없다는 소견들을 뒷받침 해준다. 나중 에는 결국 이온 농도가 떨어지지만, 이것은 아마도 병리학 적인 변화에 의해서 일어나는 현상인 것으로 생각된다. 내 림프내 이온농도 항상성과 내림프 volume 항상성은 별개 의 과정에 의해서 생긴다는 것을 가르킨다. 메니에르병 환자에서 내림프낭에 eosinophilic intraluminal precipitate가 정상인에서보다 높은 빈도로 발견되고 있어서, 
이것은 volume 조절의 역할을 하고 있고, ${ }^{12)}$ 내림프 수종 의 발생이 이것에 의한 내림프낭의 비정상적인 volume 분비에 의해 발생된다는 가설도 가능하다고 하겠다.

\section{Presence of Sinus of Endolymphatic Duct as a One-Way Valve}

Salt에 의하면 내림프낭은 다음과 같은 세가지 이유로 내림프와 외림프간의 압력차이를 감별해 낼 수 없다. 첫 째, 내림프관(endolymphatic duct) 연부조직 때문에 외 림프가 들어갈 수 없다. 둘째, 내림프낭의 압력은 sigmoid sinus와 CSF 의 압력변화에 영향을 받는다. 셋째, 내림프 낭의 압력 측정은 sigmoid sinus대문에 매우 noisy하다 는 점을 들고 있다(unpublished observation). Salt는 가장 최근 연구에서 기니픽 와우 기저부 고실계( 외림프) 에서 $1.5 \mathrm{uL} / \mathrm{min}$ 로 인공 외림프액을 흡인하였을 때, 대 부분의 관찰에서( 6 of $9,66 \%)$ 내림프낭의 $\mathrm{K}^{+}$농도와 내림프낭 전압(endolymphatic sac potential, ESP)이 감소하였고, 반대로 주입하였을 때는 별 변화가 없었다 (10 of $12,83 \%$ )라고 보고 ${ }^{5}$ 하였다. 반면에, 외림프에 주입하는 대신에, 와우관에 인공 내림프액을 $0.079 \mathrm{uL} /$ $\min$ 로 주입하였을 때는 내림프낭의 $\mathrm{K}^{+}$농도와 $\mathrm{ESP}$ 는 매우 민감하게 반응하였다. 그리고, infrasonic stimulation
을 주었을 때, longitudinal endoly mphatic movement 가 일어난다는 과거의 결과 ${ }^{14)}$ 를 바탕으로, $0.3 \mathrm{~Hz}$ 의 infrasonic sound를 ear canal로 5 cycle을 주었을 때에 (총 $1.6 \mathrm{~s}$, peak pressure $8.8 \mathrm{mmHg}$ ), $\mathrm{ESP}$ 의 변화는 관찰되지 않았지만, 자극 후 약 1 분후에 내림프낭 $\mathrm{K}^{+}$농 도가 증가하였고 자극이 없어지자 바로 회복됨을 관찰 하였다.

또한, 전정수도관이 전정과 연결되는 부위를 자세히 보 기 위해서, $20 \mathrm{um}$ 의 절편을 넣은 조직학적 소견에서, 전 정수도관이 구형낭으로 연결되기 전에 bulb- like structure를 보이는 endoly mphatic sinus를 볼 수 있다 Fig. 3).

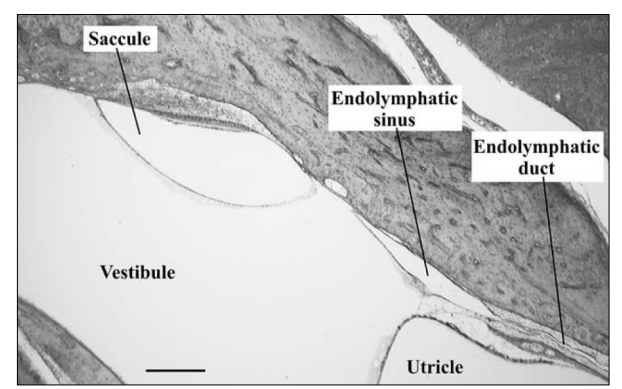

Fig. 3. Horizontal section through the vestibule of the guinea pig at the location where the endolymphatic duct enters. The duct opens into a bulb-like structure, the endolymphatic sinus. The calibration bar is 25 um ( adapted from Salt and Rask-Andersen, 2004) .

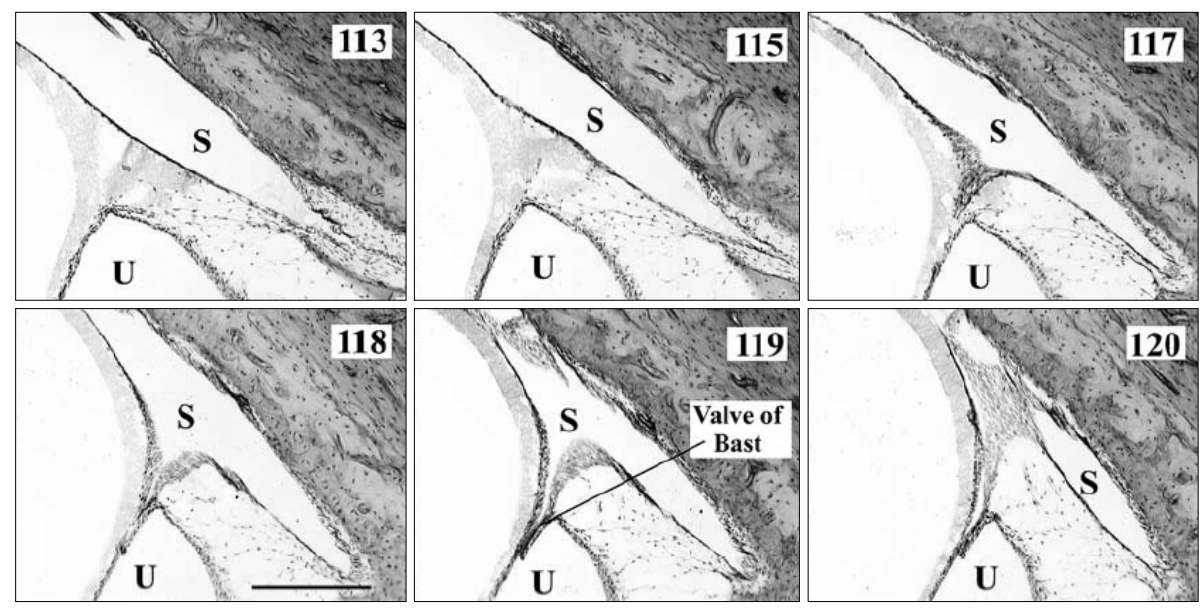

Fig. 4. Serial 20 um thick sections through the sinus of the endolymphatic duct. The numerals indicate the section number, with lower numbers representing more vertical sections. The figure shows the relationship to the endolymphatic duct (entering at the lower right of sections 113 and 115) and to the valve of Bast (section 119). Abbreviations are S : endolymphatic sinus, $\mathrm{U}$ : utricle. The calibration bar is $25 \mathrm{um}$ ( adapted from Salt and Rask-Andersen, 2004). 
Fig. 4에서 볼 수 있듯이, endoly mphatic sinus는 전정 수도관과 잘 이어져 있으며, 수직방향으로 잘리면서 endolymphatic sinus 벽이 두꺼워져 보이면서 valve of Bast를 통해서 난형낭과 연결되고, 이러한 endoly mphatic sinus는 넓은 구형낭과 연결되기 직전에 좁아져 있 다(그림 생략). Endolymphatic sinus의 용량은 약 13 $\mathrm{pL}$ 로 계산되며, 이것은 기니픽 내림프낭 용량의 $10^{4}$ 배 적은 수치이다.

상기 관찰에서 보이는 소견들을 종합하여, 외림프액 압 력 조절이 endolymphatic sinus에 미치는 영향을 정리 하여 추론한 것이 Fig. 5이다. 즉, endolymphatic sinus 는 전정수도관으로 들어가는 내림프액에 대해 barrier 역할을 할 수 있다는 설명이다. 내림프 이동은 전정과 내림프낭 사이의 압력 차이에 의해서도 영향을 받지만, endolymphatic sinus의 팽창 정도에 영향을 주는 요소 들, 즉, 내림프와 외림프의 압력 차이에 의해서도 영향 을 받을 수 있다는 점이 새로운 발견이라 하겠다. 따라 서, endoly mphatic sinus는 내림프 volume을 조절하는 데 중요한 역할을 할 것으로 생각되며, 내림프 조절은 과 거에 생각했었던 보다 복잡한 과정일 것으로 생각된다. 또한, 지속적인 조절과정이 아니라, 저작운동, 중이근육

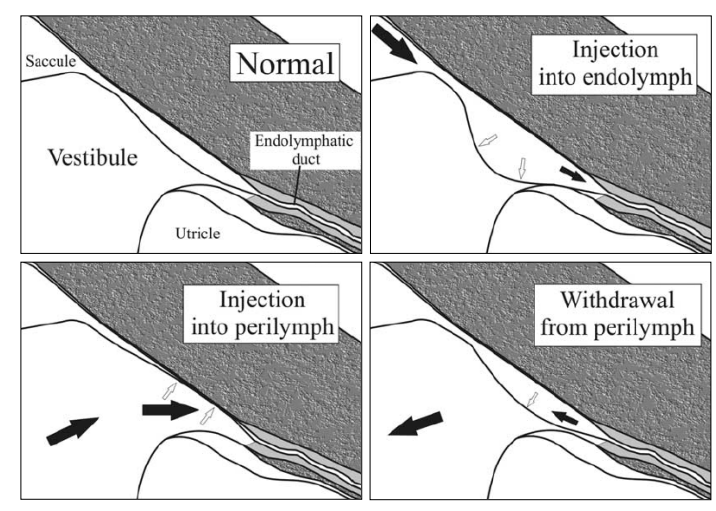

Fig. 5. Schematic showing the proposed influence of fluid manipulations on sinus of the endolymphatic duct. Injections into endolymph ( upper right) would be expected to stretch the structure, increasing sinus volume. Increase of perilymph pressure by injection ( lower left) would collapase the structure, limiting the amount of endolymph, driven into the sac. Decrease of perilymph pressure by withdrawl ( lower right) would permit endolymph to move from the sac to the sinus, thereby causing pressure and composition changes in the sac (adapted from Salt and Rask-Andersen, 2004).
수축 등에 의해 유발된 압력 변동중에 비지속적인 과정 으로서 발생될 수도 있을 것이다. 따라서, 메니에르병에 서 endolymphatic sinus의 어떤 변화에 대한 연구는 가 치가 있을 전망이다.

최근 Meniett portable device를 이용하여 중이 환기 관을 통한 alternating pressure change $(6 \sim 9 \mathrm{~Hz})$ with sustained pressure를 가하여 증상의 개선이 보고 ${ }^{15-17)}$ 되고 있지만, 여전히 그 기전은 설명되고 있지 않다. Salt 의 관찰에서 생각해 보면, infrasonic pressure change 가 내림프를 내림프낭 쪽으로 움직이게 할 수 있지만, Salt의 관찰은 중이 환기관없이 외이도에 준 것이어서 직접 비교는 곤란하다. 다만, Meniett의 경우는 이소골 움직임을 피해 정원창을 통한 압력 전달이 될 수 있겠지 만, 이런 연구 결과는 아직 없다는 점을 밝혀둔다.

\section{Function of the Endolymphatic Sac}

내림프낭은 내림프의 항상성 조절에 관여하는 것으 로 생각되면서, 메니에르병을 이해하는 데에 중요하게 생각되고 있다. 메니에르 심포지움에서도 내림프낭에 대한 short symposium을 할 만큼 미개척 분야라 할 수 있다. 따라서, 내림프낭의 역할에 대한 연구가 향후 좋 은 주제라고 생각되며, 서서히 그 역할이 알려지고 있는 단계이다.

Cellular types in the epithelium of endolymphatic sac

두 가지의 세포형태가 있으며, 예전에는 세포질의 electron density 의 차이로 light cell과 dark cell로 명 명 ${ }^{18}{ }^{20)}$ 되던 것이, 현재에는 ultrastructure차이를 기준 으로 각각 mitochondria rich cell(MRC) 과 ribosomerich cell(RRC, 혹은 chief cell) 로 명명 ${ }^{21) 22)}$ 하는 것이 적당하다고 하겠다. $\mathrm{MRC}$ 는 Fig. 6에서 보듯이 둥글게 생긴 모양으로 내림프낭으로 돌출되어 있으며, 수 많은 microvilli가 있어 신장의 intercalated cell과 비슷하며, tubulo- cisternal endoplasmic reticulum(TER)이 있 다. RRC는 평평하며, 짧은 microvilli가 있으며, 신장의 principal cell과 같이 하나의 kinocilium이 있다. 표면에 신장의 principal cell같이 A quaporin- 2(AQP- 2)가 모 

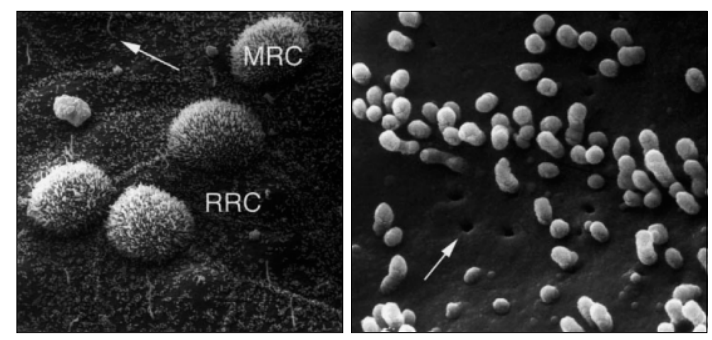

Fig. 6. Organotypic culture of endolymphatic sac from postnatal rat. Left : Scanning electron micrograph ; polygonally shaped RRC and round MRC can be identified, similar to adult native endolymphatic sac. RRC cells have stubby microvilli and are endowed with one kinocilium (arrow) like principal cells in the kidney collecting dut ; MRCs with numerous microvilli resemble intercalated cells in collecting duct epithelia. Right : higher magnification reveals clathrin-coated pits ( arrow) of the luminal membrane in the polygonal, flat RRC of the endolymphatic sac ( adapted from Kumagami et al, 1998) .

여 있다고 생각되는 clathrin- coated pit가 있다. 이 두 가지 세포의 역할은 결론적으로 말해, 내림프 조절에 중 요할 것이긴 하지만, 아직 확실히 알지 못한다. $\mathrm{MRC}$ 는 water and ion transport, proton absorption/secretion, secretion of macromolecule 등 ${ }^{12)}{ }^{23)}$ 일 것으로 생 각되지만, 잘 알려진 기전은 없다. RRC도 역시 water and ion transport, macromolecule secretion/absorption, secretion of lytic enzyme 등 ${ }^{12) 22)}$ 이 알려져 있 지만, 무엇이 주요 기능인지 알려져 있지 않고, 제시된 가능성의 증거도 부족하다. 따라서, 전체적으로 내림프낭 의 정확한 기능에 대해서는 아직 잘 알지 못하는 상태이 다. 하지만, Kagawa University 의 Nozomu Mori는 메 니에르 심포지움에서, MRC에 $\mathrm{Na}^{+}, \mathrm{K}^{+}$- ATPase가 많 이 존재하며, 높은 $\mathrm{Na}^{+}$permeability 를 보이는 점으로 보아, $\mathrm{MRC}$ 가 내림프낭에서 $\mathrm{Na}^{+}$의 흡수 기능을 하며 항 상성 유지에 중요한 역할을 할 것이다 하였다 unpublished observation).

Ion transport mechanism in the epithelial cells of endolymphatic sac

기니픽에서 patch- clamp study ${ }^{24)}$ 와 면역조직화학적 염색방법 ${ }^{25)}$ 으로 Epithelial $\mathrm{Na}^{+}$channel( $\left.\mathrm{ENaC}\right)$ 의 존 재와 basolateral membrane에 $\mathrm{Na}^{+}, \mathrm{K}^{+}$- ATPase의 존재 ${ }^{26) 27)}$ 는 $\mathrm{Na}^{+}$이 apical membrane에서(즉, 내림프
낭 luminal side로부터) 흡수되어 basolateral membrane으로 배출된다는 일반적인 $\mathrm{Na}^{+}$- absorbing epithelial cell의 기능을 생각하게 하지만, 무슨 세포에서 기록된 것인지 구분되어 기술이 되어 있지 않다는 데에 문제가 있다. 그외 outward- rectified $\mathrm{K}^{+}$channel, ${ }^{28)}$ ATP- activated nonselective cation channel, ${ }^{29)}$ calcium- sensitive nonselective cation channel, ${ }^{30)}$ apical $\mathrm{K}^{+}$conductance와 $\mathrm{Na}^{+}, \mathrm{K}^{+}, 2 \mathrm{Cl}^{-}$cotransporter의 존 재 $^{31)}$ 등이 보고되어 있다. Cincinnati Children's Hospital의 Daniel Choo에 의하면 mouse 내림프낭에서 acidbase regulator 들의 표현을 조사하였는데, pendrin, vacuolar $\mathrm{H}^{+}$- ATPase가 carbonic anhydrase II가 표현 되는 같은 세포 apical membrane에 있는 것을 보고하여, 내림프낭의 $\mathrm{pH}$ 조절에 관여할 것 이라 하였다 unpublished observation).

\section{Macromolecule in the endolymphatic sac}

내림프낭에 존재하는 macromolecule은 주로 acidic (gly cosylated) protein이다. 내림프낭의 단백질 농도는 다른 내림프보다도 상당히 높은 수준이다. A utoradiographical연구와 면역조직화학적 연구에서 밝혀진 단백 질은 다음과 같이 다양하다. 1) Tyrosine- containing protein, 2) sulfated glycoprotein, 3) N- acety lgalactosamine, $\mathrm{N}$ - acety lglucosamine, fucose, galactose, glucose, mannose, 4) hy aluronan, chondroitin- 4sulfate, dermatan sulfate, keratan sulfate 등 ${ }^{32)}$ 이다. 이런 macromolecule들이 내림프낭의 삼투압을 조절하 는 역할을 할 것으로 생각되지만, 저자에 따라서 차이가 있고, 어느 세포에서 생성, 분비, 흡수, 분해되는지, 그 기 전이 무엇인지 명확하지 않다.

\section{Herpes simplex virus in the endolymphatic sac}

House Ear Institute의 Linthicum의 발표는 눈길을 끈다. Herpes simplex virus(HSV) gly coprotein B가 메니에르 환자 25명중 23명의 내림프낭에서 검출된 반 면, 대조군 24 명중 2 명만이 검출되어 viral etiology in the sac의 가능성을 제시한 바 있다. 반면에, Gaertner 등은 메니에르 환자의 수술 중 얻은 vestibular ganglion에서는 HSV 를 발견할 수 없었다고 보고한 바 있다 
(unpublished observation).

\section{Suggestions Favoring Endolymph Over-Production as a Mechanism of Endolymphatic Hydrops}

이 부문은 주로 Kansas State University 의 Daniel C. Marcus와 Philine Wangemann에 의해 보고가 많이 되어 왔다. 혈관조(stria vascularis) 의 변연세포(marginal cell) 는 내림프를 생성하는 곳으로 알려져 있어서, 여러가지 호르몬의 target으로 생각되어 많은 연구가 되 어 온 부분이다. 혈관조 변연세포는 basolateral membrane에 $\beta$ 1- adrenergic receptor와 muscarinic receptor(M3, M4)의 조절을 받는다. ${ }^{33)} V$ asopressin과 $\beta 2$ - adrenergic receptor는 없는 것으로 알려져 있다. $\beta$ 1- adrenergic receptor는 Gs protein- adenyly l cyclase- cAMP system과 연결되어 있어 내림프내 $\mathrm{K}^{+}$ 분비를 증가시킨다. 메니에르병 환자에서 발견되는 norepinephrine농도의 증가가 $\beta$ 1- adrenergic receptor를 자극하여 $\mathrm{K}^{+}$분비를 증가시켜 내림프 수종을 일으킬 수 있다는 설명이 가능하다. ${ }^{34)}$ 흥미로운 것은 muscarinic acetylcholine receptor는 세포내 $\mathrm{Ca}^{2+}$ 의 증가, cAMP 를 증가시켜 $\mathrm{K}^{+}$분비를 감소시킨다. acety lcholine은 주 요 efferent neurotransmitter 인데, 혈관조에는 신경 지 배가 없으므로, 아마도 혈장에서 오는 acetylcholine의 영향을 받지 않을까 추측이 되고 있다. ${ }^{35)}$

최근에는 semicircular canal duct의 결과들이 보고되 고 있다. Semicircular canal duct를 배양하여 Ussing chamber방법으로 이온의 움직임을 조사한 결과, luminal side쪽으로 $\mathrm{Cl}^{-}$secretion ${ }^{36)}$ 과 basolateral membrane 방향으로 $\mathrm{Na}^{+}$absorption ${ }^{37)}$ 이 있음을 알게 되었다. $\mathrm{Cl}^{-}$ secretion은 혈관조 변연세포와는 달리 $\beta$ 2- adrenergic receptor의 조절을 받고 있다. 이것 또한 메니에르병에 서 $\mathrm{Cl}^{-}$의 과분비로 인한 내림프 수종이 발생할 수 있다 는 가능성이 제시되고 있다. 배양세포에서 glucocorticoid를 처치 하였더니, $\mathrm{Na}^{+}$aborption이 증가되었는데, 메니에르병 환자에서 스테로이드가 반응을 보이는 하나 의 기전일 수 있다는 가능성도 같이 제시되고 있다. ${ }^{37)}$ 그러나, 메니에르병의 내림프 수종이 $\mathrm{Na}^{+}, \mathrm{Cl}^{-}$의 과분
비, $\mathrm{Na}^{+}$의 저흡수 중에서 어떤 것이 주 역할을 하는지 알지 못하는 상태에서, 어떤 한 가지를 선택하기는 무리 인 듯 보인다.

\section{Pharmacologic and Acoustical Models of Endolymphatic Hydrops}

1938년 Hallpike와 Carins ${ }^{38)}$ 에 의해 처음으로 메니 에르병 환자의 병리학적 소견이 내림프 수종으로 밝혀 졌다. 1965년 Kimura와 Schuknecht ${ }^{39)}$ 가 처음으로 endolymphatic sac obliteration방법으로 동물 모델을 만든 이후에, 현재까지도 많은 연구자들이 이 방법을 이 용하여 내림프 수종을 만든 후에 형태학적, 전기생리학 적으로 연구하고 있다. 하지만, 이 모델은 내림프낭에서 내림프의 흡수부전이 내림프 수종을 일으킨다는 전제하 에 성립되는 것이다. 만약, 메니에르병의 기전이 다른 이 유라면, 이런 비생리학적인 방법(mechanical, non- physiologic method)에서 얻어지는 각종 데이타와 발생기전 에 대한 추론은 중요성을 상실하게 된다는 사실을 간과 하면 안된다. 이런 관점에서 내림프낭을 묶지 않고, 전신 적으로 약을 투여하거나, 소리자극을 주어서 내림프 수 종을 만든 모델들은 고무적이라 할 수 있다. 현재까지로 는 3개가 보고되어 있는데, 1) stress hormone인 vasopressin을 투여하여 만든 모델, ${ }^{21) 40)}$ 2) 세포내 CAMP 를 증가시키는 cholera toxin을 이용한 방법, ${ }^{41)}$ 3) nontraumatic low- frequency tone을 외이도에 주어 만든 모델 ${ }^{42)}$ 등이 보고되어 있다.

V asopressin을 이용하여 T akeda 등이 만든 방법은 mini- osmotic pump를 이용하여 1주일간 각각 다른 용 량으로 지속적으로 subcutaneous infusion하였다. 고용 량인 $1000 \mathrm{uU} / \mathrm{kg} / \mathrm{min}$ 을 주었을 때, 모든 회전에서 와 우관의 유의한 면적 증가가 관찰되었으며, 그 정도는 첨 부에서 가장 심했다. 이 보고의 신빙성을 높이는 요소로 서는 혈장 vasopressin 농도가 $14 \mathrm{pg} / \mathrm{ml}$ 로서 사람의 메니에르병 발작대의 농도와 유사한 것을 보여준 점이다. 반면에 1998년에 Kumagami 등리 이 vasopressin을 이 용하여 만든 것은 혈중 농도에 대한 조사가 없었다. 400 $\mathrm{uU} / \mathrm{kg} / \mathrm{min}$ 을 주입한 경우 각 회전별로 비교 하였을 때 는, 유의한 면적의 증가가 없지만, 전체 면적을 비교하 
면 유의하게 증가되었다. 하지만, 과연 vasopressin의 target이 어디이며, 그 기전에 대한 증거는 없다.

그러면, 과연 vasopressin의 target은 어디 인가? 내 림프내 $\mathrm{K}^{+}$을 분비하는 혈관조는 아닌 것 같다. 왜냐하 면, Wangemann 등 ${ }^{43)}$ 이 보고한 바에 의하면 분리된 혈 관조를 이용한 micro- Ussing chamber 실험에서10 nM vasopressin(생리학적으로 가능한 가장 높은 농도를 처 치하였을 때, 혈관조의 가장 중요한 기능인 $\mathrm{K}^{+}$분비가 영향을 받지 않았기 때문이다. 저자가 신생쥐 혈관조를 이용하여 같은 약을 써서 조사한 바에 의해도 별 반응이 없었다( unpublished observation). 한가지 가능성은 남 아 있다고 생각된다. Vasopressin이 이온 통로를 직접 활성화시키지는 않고, 원래 역할인 AQP- 2를 세포질에 서 apical membrane으로 trafficking시켜 water perameability 를 높이기만 한다면, 이온 움직임만을 관찰하 는 측정 방법으로는 양성 반응을 놓칠 수도 있었을 가능 성은 남아 있다 하겠다.

현재로서는 내림프낭은 풍부한 증거에 근거하여 vasopressin의 target이라고 말할 수 있다. 그 중에서 Kumagami 등 ${ }^{21)}$ 의 결과는 vasopressin의 기능을 설명 해 주고 있어서 특별한 언급이 필요하다. 내림프낭에서 AQP- 2와 vasopressin ty pe 2 receptor $\left(V_{2}\right.$ receptor) $\mathrm{mRNA}$ 가 검출되었고, emulsion autoradiography 로 radiolabelled vasopressin이 human 내림프낭에 접착 되었으며, 동시에 고용량의 vasopressin을 한번 준 그 룹중에서는 20마리중 8예에서 내림프 수종이 발견되었 고, 60 일간 지속적으로 준 그룹에서는 10마리중 7 예에 서 내림프 수종이 발생됨을 보고하였다. 한편, 과연 vasopressin의 기전에 대해서는 예상밖의 결과를 얻었는데, 다음과 같이 기술된다.

앞에 언급한 clathrin- coated pits는 신장 collecting duct의 principal cell에 의하면 AQP- 2가 모여 있는 곳인데, ${ }^{44)}$ fluid- phase endocytosis 최근 연구에 의하 면, principal cell membrane turnover는 AQP- 2의 세 포질에서의 apical membrane으로의 trafficking이 관계 한다고 한다. ${ }^{45)}$ 따라서, Kumagami 등은 fluid- phase endocy tosis 방법을 이용하여 내림프낭 RRC에 FIT Cdextran uptake가 $1 \mathrm{nM}$ vasopressin에 의해 억제되며, 이 효과가 $V_{2}$ receptor antagonist $(H-9400)$ 에 의해

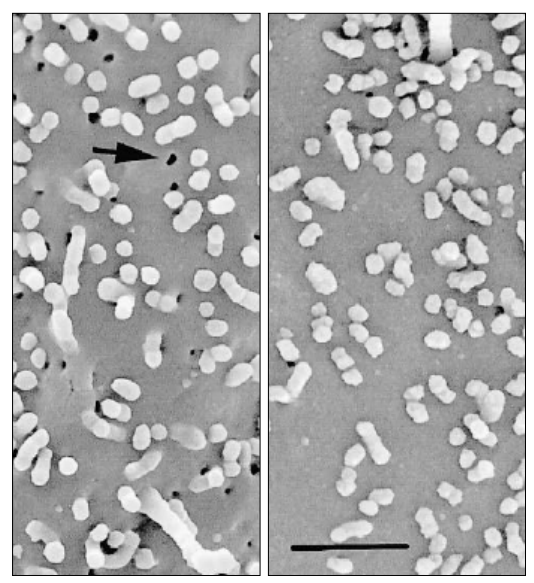

Fig. 7. Scanning electron microscopy in the ribosomerich cell (RRC) of the endolymphatic sac. Left : Under control conditions, RRC contain numerous coated pits (arrow). Scale bar is 1 um. Right : Almost no coated pits were visible after treatment with $1 \mathrm{nM}$ vasopressin, indicating internalization of clathrin, prsumably clustered with aquaporin-2 (adapted from Kumagami et al, 1998) .

서 억제됨을 관찰하였고, 이러한 memebrane turnover 의 억제가 scanning electron microscopy 로는 내림프 낭 RRC에 보이던 clathrin- coated pits가 없어지는 것 에 해당됨을 관찰하였다(Fig. 7). 이러한 사실을 바탕으 로 vasopressin이 신장에서는 AQP- 2를 stimulation하 지만, 내림프낭에서는 inhibition하는 반대의 작용을 하 는 것 같다고 보고하였다. 즉, 신장에서는 water reabsorption을 증가시키고, 내림프낭에서는 감소시켜서 내 림프 수종을 발생시킨다는 가설이 가능하다 하겠다. 그 러나, 메니에르병 환자에서 hyponatraemia같은 심한 vasopressin excess에 이환되어 있다는 증거가 없다. ${ }^{46)}$ 혹시, vasopressin에 내림프낭이 hy persensitivity 가 있 다면 설명이 가능할 수도 있다. T akeda 등 ${ }^{47)}$ 은 $\mathrm{V}_{2}$ receptor antagonist인 OPC- 31260을 내림프낭을 파괴 하여 만든 기니픽 내림프 수종 모델에 주사하여 내림프 수종이 줄어들었음을 보고하면서, 와우와 내림프낭에서 의 vasopressin- AQP- 2 system의 중요성을 설명하였 지만, 앞의 모델과 직접적으로 연관을 지을 수는 없다는 단점이 지적된다.

한편, 임상적으로는 메니에르병 환자의 경우 혈중 vasopressin 농도가 높게 보고 된 것에 대해 대립되는 보 고가 계속되고 있다. 예를 들면, 메니에르 심포지움에서 
도, Gifu University 의 A ndo 등은 psychologic status 까지 조사해 가면서 상승된 혈중 농도가 attack 당시의 정신적인 문제가 아니라, 귀의 상태에 관여하는 것이라 하였지만, Christchurch Hospital의 Hornibrook은 혈 중 농도가 높지 않음을 보고하면서, attck 당시의 메니에 르 환자의 구토, 오심 증상이 그 원인일 것이라 하였다 (unpublished observation).

두번째 모델은, 기니픽 고실계에( perilymphatic infusion) $2.5 \mathrm{ul} / \mathrm{min}$ 으로 15 분간 $10 \mathrm{ug} / \mathrm{ml}$ cholera toxin 을 투여한 모델이다. 사실, 그 전의 두개의 실험 보고 들 $^{48)}{ }^{49)}$ 도 $\mathrm{CAMP}$ 의 농도를 올리는 약(cholera toxin, forskolin) 을 투여하여 내림프의 과생성에 의해서 내림 프 수종이 발생되는 것 같다는 보고들은 있었지만, 전기 생리학적, 형태학적 증거가 제시되지 않았다. 이 보고에 서는 아주 경한 내림프 수종, endocochlear potential (EP)의 $17 \mathrm{mV}$ 증가, summating potential(SP) 증가, compound action potential( CAP)의 감소 등을 관찰하 였는데, $\mathrm{EP}$ 의 증가는 내림프낭을 묶음으로써 생기는 내 림프 수종대에 관찰되는 $\mathrm{EP}$ 감소 ${ }^{50) 51)}$ 와 대조되고, 뒤의 두 요소는 동일한 결과이다. EP 증가는 cholera toxin 에 의해서 혈관조 변연세포의 $\mathrm{K}^{+}$분비 증가 ${ }^{52)}$ 와 Reissner's membrane을 통한 $\mathrm{Cl}^{-}$이동의 증가 ${ }^{53)}$ 를 생각 할 수 있지만, 후자의 경우 계산상 약 $5 \mathrm{mV}$ 정도밖에 기여하지 못한다는 문제가 있다. 따라서, EP증가의 원인 이 전자와 후자 중에서 아직 확실히 설명되고 있지는 않 다. $\mathrm{SP}$ 는 $2,4,8 \mathrm{kHz}$ 중에서 $2 \mathrm{kHz}$ 에서 가장 높게 증가 하였는데, 와우 첨단부에서 기저막의 stiffness가 가장 적기 때문에, 내림프내 같은 압력이 있다 하더라도 그 부 분에서 가장 많이 고실계쪽으로 부풀게 되어, 흔히 말하 는" setpoint of cochlear transducer"의 변화를 가져 오는 것이라고 생각된다. 내림프낭이 관여하지 않더라도 와우 자체만으로도 내림프 수종이 올 수 있다는 점을 유 추해 낼 수 있다는 데에 의미가 있다.

세번째 모델은 2004년에 Salt가 기니픽 외이도에 115 $\mathrm{dB}$ SPL로 $200 \mathrm{~Hz}$ tone을 3분간 주었을때, 가역적인 일 시적 내림프 수종의 발생, 와우 기저부로 향하는 내림프 이동의 소견, EP 증가 등을 보고한 모델이다. ${ }^{42)}$ Action potential (AP)과 내림프내 $\mathrm{K}^{+}$변화는 미약하였다. 내 림프 수종과 $\mathrm{EP}$ 는 $200 \mathrm{~Hz}$ 에서 $95 \mathrm{~dB}$ SPL에서부터 증
가시키며 관찰하였는데, 결과는 $115 \mathrm{~dB}$ SPL 부터 내림프 수종에 해당하는 cross- sectional area의 증가 $33.7 \%$ ) 와 $\mathrm{EP}$ 의 증가가 관찰되었다. 와우 기저부로 향하는 내림 프의 이동은 불과 $4 \%$ 의 용량이 움직이는 것으로 계산되 었다. 이렇게 적은 이동으로 생각해 볼때, 내림프내 압력 과 용량의 증가 관계는 nonlinear relationship을 갖는 것 $^{54)}$ 으로 보여진다. AP threshold의 변화는 내림프 면 적이 변화하지 않는 자극인 $95 \mathrm{~dB}$ SPL에서부터 발견 되었다. Kirk and Patuzzi ${ }^{55)}$ 는 operating point shift에 대해서 organ of Corti가 고실계쪽으로 이동되는 경향 과 더불어 organ of Corti를 통한 전류 흐름의 감소로 정 의한 바 있다. Salt의 결과로는 operating point shift는 내 림프내 용량의 변화에 기인하는 것이 아니라, 반대로 내림 프내 용량의 변화가 operating point of cochlear tranducer의 변화에 기인하는 것 같다 하였다. AP threshold 의 변화가 미약한 반면, 용량의 변화는 $37.7 \%$ 의 변화 가 있었기 때문에, 내림프수종에서 청력역치의 변화는 내림프 수종 자체 때문은 아닌 것 같다는 추론이 가능 하다. 즉, 내림프낭을 파괴하여 만든 동물 모델의 경우, 수 주 후부터 관찰되는 청력 감소는 아마도 다른 원인, 즉, $\mathrm{EP}$ 의 감소, 내림프내 $\mathrm{Ca}^{2+}$ 농도의 증가, 혈관조 변 성 등에 기인하는 것으로 추측될 수 있다.

\section{결 론}

최근들어, 메니에르병의 병인론에 대해 임상적, 실험적 관찰에 진전이 있어 왔지만, 아직도 만족할 만한 설명이 되고 있지 않다. 결국, 가장 중요한 것은 정상 내이 생 리를 밝혀야 병적인 상태를 이해할 수 있다는 원론적인 생각에 머무르게 된다. Michael M. Paparella의 믿음대 로 multifactorial inheritance라 하더라도, 그 기전을 밝 히려는 노력은 중요하다 하겠다. 현재의 약물 치료와 수 술적 치료가 대부분의 메니에르병 환자의 증상을 호전시 키고 있지만, 어떤 기전으로 작용되는지에 대한 증거는 없다고 단정지을 수 있다. 2005년 4월에 열렸던 5th Meniere's Disease \& Inner Ear Homeostasis Disorders Symposium에서도 여기에 기술된 내용 대부분이 발표 된 바 있다. Pathophy siology 분야에서는 여러 분야의 관점을 통합하는 연구가 필요하리라 생각이 들었다. 5년 
후 일본에서 개최되는 메니에르 심포지움에서는 좀 더 발전된 연구결과들이 발표되리라 기대해 본다.

중심 단어 : 메니에르병. 와우 내림프낭. 내림프수종.

본 연구는 2005년도 보라매병원 임상연구비의 지원에 의해 이루어졌음.

\section{REFERENCES}

1) Paparella MM, Djalilian HR. Etiology, pathophysiology of symptoms, and pathogenesis of Meniere's disease. Otolarynool Clin North Am 2002;35(3):529-45.

2) Paparella MM, Fina M. Endolymphatic sac enhancement: reversal of pathogenesis. Otolaryngol Clin North Am 2002; 35(3):621-37.

3) Sando I, Orita Y, Hirsch BE. Pathology and pathophysiology of Meniere's disease. Otolaryngol Clin North Am 2002;35 (3): $517-28$.

4) Salt AN. Regulation of endolymphatic fluid volume. Vestibular Labyrinth in Health and Disease 2001;942:306-12.

5) Salt AN, Rask-Andersen H. Responses of the endolymphatic sac to perilymphatic injections and withdrawals: evidence for the presence of a one-way valve. Hear Res 2004;191(12):90-100.

6) Konishi T, Hamrick PE, Walsh PJ. Ion transport in guinea pig cochlea. I. Potassium and sodium transport. Acta Otolaryngol 1978;86(1-2):22-34.

7) Konishi T, Hamrick PE. Ion transport in the cochlea of guinea pig. II. Chloride transport. Acta Otolaryngol 1978; 86(3-4): 176-84.

8) Sterkers O, Saumon G, Tran Ba HP, Amiel C. $\mathrm{K}, \mathrm{Cl}$, and $\mathrm{H} 2 \mathrm{O}$ entry in endolymph, perilymph, and cerebrospinal fluid of the rat. Am J Physiol 1982;243(2):F173-F80.

9) Salt AN, Thalmann R. Interpretation of endolymph flow results: a comment on 'Longitudinal flow of endolymph measured by distribution of tetraethylammonium and choline in scala media'. Hear Res 1988;33(3):279-84.

10) Salt AN, Demott JE. Endolymph Volume Changes During Osmotic Dehydration Measured by 2 Marker Techniques. Hearing Research 1995;90(1-2):12-23.

11) Salt AN, DeMott J. Longitudinal endolymph flow associated with acute volume increase in the guinea pig cochlea. Hearing Research 1997;107(1-2):29-40.

12) Rask-Andersen H, Demott JE, Bagger-Sjoback D, Salt AN. Morphological changes of the endolymphatic sac induced by microinjection of artificial endolymph into the cochlea. Hearing Research 1999;138(1-2):81-90.

13) Salt AN. Regulation of endolymphatic fluid volume. Ann $N$ Y Acad Sci 2001;942:306-12.

14) Salt AN, Demott JE. Longitudinal endolymph movements and endocochlear potential changes induced by stimulation at infrasonic frequencies. Journal of the Acoustical Society of America 1999; 106(2):847-56.

15) Densert B, Sass K. Control of symptoms in patients with Meniere's disease using middle ear pressure applications: two years follow-up. Acta Otolaryngol 2001;121(5):616-21.

16) Gates GA, Green JD, Jr. Intermittent pressure therapy of intractable Meniere's disease using the Meniett device: a preliminary report. Laryngoscope 2002;112(8 Pt 1):1489-93.

17) Barbara M, Consagra C, Monini S, Nostro G, Harguindey A, Vestri A, et al. Local pressure protocol, including Meniett, in the treatment of Meniere's disease: short-term results during the active stage. Acta Otolaryngol 2001;121(8):939-44.

18) Friberg U, Bagger-Sjoback D, Rask-Andersen H. The lateral intercellular spaces in the endolymphatic sac. A pathway for fluid transport? Acta Otolaryngol Suppl 1985;426:1-17.

19) Hultcrantz M, Bagger-Sjoback D, Rask-Andersen H. The pre- and postnatal maturation of the epithelium in the endolymphatic sac. An electron microscopic survey. Acta Otolaryngol 1988;105(3-4):303-11.

20) Barbara M, Rask-Andersen H, Bagger-Sjoback D. Ultrastructure of the endolymphatic sac in the mongolian gerbil. Arch Otorhinolaryngol 1987;244(5):284-7.

21) Kumagami H, Loewenheim H, Beitz E, Wild K, Schwartz $\mathrm{H}$, Yamashita $\mathrm{K}$, et al. The effect of anti-diuretic hormone on the endolymphatic sac of the inner ear. Pflugers Arch 1998; 436(6):970-5.

22) Qvortrup K, Rostgaard J, Holstein-Rathlou NH, Bretlau P. The endolymphatic sac, a potential endocrine gland? Acta Otolaryngol 1999;119(2): 194-9.

23) Peters TA, Tonnaer EL, Kuijpers W, Cremers CW, Curfs JH. Differences in endolymphatic sac mitochondria-rich cells indicate specific functions. Laryngoscope 2002;112(3): 534-41.

24) Mori N, Wu D. Low-amiloride-affinity Na+ channel in the epithelial cells isolated from the endolymphatic sac of guinea-pigs. Pflugers Arch 1996;433(1-2):58-64.

25) Zhong SX, Liu ZH. Immunohistochemical localization of the epithelial sodium channel in the rat inner ear. Hear Res 2004; 193(1-2):1-8.

26) Mizukoshi F, Bagger-Sjoback D, Rask-Andersen H, Wersall J. Cytochemical localization of Na-K ATPase in the guinea pig endolymphatic sac. Acta Otolaryngol 1988;105(3-4): 202-8.

27) Wackym PA, Glasscock ME, III, Linthicum FH, Jr., Friberg $\mathrm{U}$, Rask-Andersen H. Immunohistochemical localization of $\mathrm{Na}+, \mathrm{K}+$-ATPase in the human endolymphatic sac. Arch Otorhinolaryngol 1988;245(4):221-3.

28) Wu D, Mori N. Outward K+ current in epithelial cells isolated from intermediate portion of endolymphatic sac of guinea pigs. Am J Physiol 1996;271(5 Pt 1):C1765-C73.

29) Wu D, Mori N. Extracellular ATP-induced inward current in isolated epithelial cells of the endolymphatic sac. Biochim Biophys Acta 1999;1419(1):33-42.

30) Miyashita T, Tatsumi H, Furuta H, Mori N, Sokabe M. Calcium-sensitive nonselective cation channel identified in the epithelial cells isolated from the endolymphatic sac of guinea pigs. J Membr Biol 2001;182(2):113-22.

31) Teixeira M, Couloigner V, Loiseau A, Hulin P, Sterkers O, Planelles G, et al. Evidence for apical $K$ conductance and $\mathrm{Na}-\mathrm{K}-2 \mathrm{Cl}$ cotransport in the endolymphatic sac of guinea pig. Hear Res 1999;128(1-2):45-50.

32) Peters TA, Tonnaer EL, Kuijpers W, Curfs JH. Changes in 
ultrastructural characteristics of endolymphatic sac ribosome-rich cells of the rat during development. Hear Res 2003; 176(1-2):94-104.

33) Wangemann P. Adrenergic and muscarinic control of cochlear endolymph production. Adv Otorhinolaryngol 2002;59: 42-50.

34) Wangemann P, Liu J, Shimozono M, Schimanski S, Scofield MA. $K(+)$ secretion in strial marginal cells is stimulated via beta (1)-adrenergic receptors but not via beta (2)-adrenergic or vasopressin receptors [In Process Citation]. J Membr Biol 2000;175(3):191-202.

35) Wangemann P, Liu J, Scherer EQ, Herzog M, Shimozono M, Scofield MA. Muscarinic receptors control $K+$ secretion in inner ear strial marginal cells. Journal of Membrane Biology 2001;182(3):171-81.

36) Milhaud PG, Pondugula SR, Lee JH, Herzog M, Lehouelleur J, Wangemann P, et al. Chloride secretion by semicircular canal duct epithelium is stimulated via beta (2)-adrenergic receptors. American Journal of Physiology-Cell Physiology 2002;283(6):C1752-C60.

37) Pondugula SR, Sanneman JD, Wangemann P, Milhaud PG, Marcus DC. Glucocorticoids stimulate cation absorption by semicircular canal duct epithelium via epithelial sodium channel. Am J Physiol Renal Physiol 2004;286(6):F1127-F35.

38) Hallpike CS, Carins H. Observations on the pathology of Meniere's syndrome. J Laryngol Otol 1938;53:625-55.

39) Kimura RS, Schuknecht HF. Membranous hydrops in the inner ear of the guinea pig after obliteration of the endolymphatic sac. Oto-Rhino-Laryngol 1965;27:343-54.

40) Takeda T, Takeda S, Kitano H, Okada T, Kakigi A. Endolymphatic hydrops induced by chronic administration of vasopressin. Hear Res 2000;140(1-2):1-6.

41) Lohuis PJ, Klis SF, Klop WM, van Emst MG, Smoorenburg GF. Signs of endolymphatic hydrops after perilymphatic perfusion of the guinea pig cochlea with cholera toxin; a pharmacological model of acute endolymphatic hydrops. Hear Res 1999; 137(1-2):103-13.

42) Salt AN. Acute Endolymphatic Hydrops Generated by Exposure of the Ear to Nontraumatic Low-Frequency Tones. $J$ Assoc Res Otolaryngol 2004; 5:203-14.

43) Wangemann P, Liu J, Shimozono M, Schimanski S, Scofield MA. $K+$ secretion in strial marginal cells is stimulated via beta (1)-adrenergic receptors but not via beta (2)-adrenergic or vasopressin receptors. Journal of Membrane Biology 2000; 175(3):191-202.

44) Brown D, Stow JL. Protein trafficking and polarity in kidney epithelium: from cell biology to physiology. Physiol Rev 1996;76(1):245-97.

45) Katsura T, Verbavatz JM, Farinas J, Ma T, Ausiello DA, Verkman AS, et al. Constitutive and regulated membrane expression of aquaporin 1 and aquaporin 2 water channels in stably transfected LLC-PK1 epithelial cells. Proc Natl Acad Sci USA 1995;92(16):7212-6.

46) Seemungal BM, Gresty MA, Bronstein AM. The endocrine system, vertigo and balance. Curr Opin Neurol 2001;14(1): 27-34.

47) Takeda T, Sawada $S$, Takeda $S$, Kitano H, Suzuki M, Kakigi $\mathrm{A}$, et al. The effects of V2 antagonist $(O P C-31260)$ on endolymphatic hydrops. Hear Res 2003;182(1-2):9-18.

48) Roheim PS, Brusilow SW. Effects of cholera toxin on cochlear endolymph production: model for endolymphatic hydrops. Proc Natl Acad Sci USA 1976;73(5):1761-4.

49) Doi K, Mori N, Matsunaga T. Effects of forskolin and 1,9dideoxy-forskolin on cochlear potentials. Hear Res 1990;45 (1-2): 157-63.

50) Cohen J, Morizono T. Changes in EP and inner ear ionic concentrations in experimental endolymphatic hydrops. Acta Otolaryngol 1984;98(5-6):398-402.

51) Kusakari J, Kobayashi T, Arakawa E, Rokugo M, Ohyama K, Inamura N. Saccular and cochlear endolymphatic potentials in experimentally induced endolymphatic hydrops of guinea pigs. Acta Otolaryngol 1986;101(1-2):27-33.

52) Wangemann P. $K+$ cycling and its regulation in the cochlea and the vestibular labyrinth. Audiology and Neuro-Otology 2002;7(4):199-205.

53) Kitano I, Mori N, Matsunaga T. Role of endolymphatic anion transport in forskolin-induced Cl-activity increase of scala media. Hear Res 1995;83(1-2):37-42.

54) Wit HP, Warmerdam TJ, Albers FW. Measurement of the mechanical compliance of the endolymphatic compartments in the guinea pig. Hear Res 2000;145(1-2):82-90.

55) Kirk DL, Patuzzi RB. Transient changes in cochlear potentials and DPOAEs after low-frequency tones: the 'two-minute bounce' revisited. Hear Res 1997;112(1-2):49-68. 